\title{
EARNINGS QUALITY ATTRIBUTES AND INVESTMENT OPPORTUNITIES FOR LATIN AMERICAN FIRMS ${ }^{1}$
}

\author{
Flávio Leonel Carvalho ${ }^{2}$ \\ Marina Barboza Camargo ${ }^{3}$ \\ Aquiles Kalatzis ${ }^{4}$
}

\begin{abstract}
This work verifies if companies with better accounting information show better performance and investigates the impact of better accounting information on the financial constraints. This study is based on an unbalanced panel data of 596 firms from seven Latin American countries between 1989 and 2009. The return on equity (ROE) and Market to book (MB) variables are used to define the firms' performance, which are regressed against five models that consider the quality of accounting information. We also investigate the relationship between financial constraint, measured by the KZ index, and accounting quality. The results support the view that earnings quality is an important factor to explain market and operational performance and aspects related to efficiency are important to determine the operational performance, but are not significant when market performance of Latin American firms are analyzed. When we model the firm's investment, the quality of accounting information appears to be a useful proxy to financial constraint. Moreover, the accounting quality plays a positive effect on investment that is a much more positive for unconstraint firms.
\end{abstract}

Keywords: Investment; Accrual Quality; Accounting Information; Mixed Model. 


\section{INTRODUCTION}

O ver the last years, due to the development of Latin American capital market, companies have been forced to search for more efficient forms to satisfy the informational necessities of stakeholders. Information theory has taken into account the disclosure standards of financial information adopted by companies, and their impact on cost of capital, share appreciation and credit access.

In general, the availability of accounting information is viewed as a way to reduce the asymmetric information among managers and shareholders, managers and creditors and between the controller shareholder and the minority ownership. One of the main objectives of accounting is to help shareholders to make decisions by considering expectations about future cash flow (Hendriksen \& Van Breda, 1999). Accordingly, it is necessary that the accounting provides a minimum quality of information and contributes towards a reduction of asymmetric information.

Moreover, over the last decade, several accounting scandals have placed in doubt the truth of accounting information. Consequently, corporate governance mechanisms, level of disclosure and quality of accrual have become important subjects for researchers and practitioners in the accounting and financial area.

Several papers have addressed the issue of accruals quality, as for instance Corea, Guay and Verdi (2008), who verified if the quality of accruals may represent a risky factor, Francis, Lafond, Olsson and Schipper (2005) investigated whether the quality of accruals is a determinant of the cost of capital, Inci, Lee and Suh (2009) examined the nature of the dynamic relationship between earnings and capital investment, Colauto \& Beuren (2006) analyzed the influence of accruals in accounting income and the net working capital variance and Coelho \& Lopes (2007), who investigated the existence of earnings management and its association with leverage for Brazilian listed firms. Many other papers have discussed the aspects of quality of accounting information and disclosure - Barth, Beaver \& Landsman (2001), Bushman \& Smith (2001), Dechow \& Dichev (2002), Francis, Schipper \& Vincent (2003) and Barbosa, Scherer, Scarpin \& Murcia (2015) - and their impact on some aspects of firms' performance - Lambert, Leuz \& Verrecchia (2007) and Mahmud, Ibrahim \& Pok (2009). These discussions are incipient in the world and mainly in Latin American countries.

While the studies mentioned above focus on the quality of accounting information, the shortage of studies considering the relationship between financial constraint and quality financial reporting is remarkable. The quality of information access can induce the estimates of external investors about return expectations, influencing the access to external capital. Although the literature ignores the existence of the relationship between financial constraint and quality of accounting information, we believe that this association can help us identify whether the financial information is a powerful proxy to financial constraint. Accordingly, we expect that the firms more likely to be financially constrained tend to present better accounting quality in order to reduce the asymmetric information and agency problem.

In this paper, we investigate the relationship between financial constraint and quality of accounting information. For this, two hypotheses will be tested. The first hypothesis posits that the accounting information have a positive and significant impact on the firm's operational performance. Second, the measure of accounting quality is a useful proxy to identity financial constraints. To illustrate the effects of financial constraint, the firms are classified into unconstrained and constrained ones, measured by 
the KZ index. The KZ index is constrained by following Lamont, Polk \& Saá-Requejo (2001) and reflects the likelihood that a firm faces financial constraints. The accounting quality is measured by using four different proxies - predictive value (PV), feedback value (FV), absolute abnormal accruals (AAA) and accruals quality (AQ) - and an additional variable - Information Quality Factor (IQF) - that was built by factor analysis with the objective to reduce the four proxies to only one variable.

This paper makes an important contribution to the literature. First, the major contribution of this paper is to discuss the role of the quality of accounting information on the performance and investment of Latin American firms. Another important contribution is that our measure of account quality plays a significant role on firms' investment, as well as being a useful proxy for the financial constraints. Thirdly, this article contributes not only to filling gap in the literature, but also to help in the understanding of behavior and reactions to different sources of financing and market with different structure from those normally studied (USA and Europe). In this sense, the paper can contribute to reaffirmation of predictive and explanatory power of theories. Finally, our work to predict investment models uses mixed models, which enable capturing the unobserved heterogeneity of the cross section units by incorporating an additional randomness on the explanatory variables, we also used a country-specific effect aiming at controlling the unobserved characteristics. However, what happen at one level need not similar at another level, the covariates at level 2, but constant at level 1, can present estimated coefficient not statistically significant.

Therefore this paper investigates the role of earnings quality on a firm's performance, using an unbalanced panel data from firms in Argentina, Brazil, Chile, Colombia, Mexico, Peru and Venezuela, from 1989 to 2009. Herein, the quality of accounting information is measured with the following proxies: predictive value (PV), feedback value (FV), absolute abnormal accruals (AAA), accruals quality (AQ) and information quality factor. (IQF). The performance of companies is measured through return on equity (ROE) and Market to Book (MB). The investment model is based on a modified version of the Accelerator model, according to Jorgenson (1963), which contains the cash flow, sales, debt and accounting quality variable. To estimate the investment model, we grouped the firms according to the KZ index, categorizing them as unconstrained and constrained firms.

The results of this paper indicate that firms with better accounting information have a better performance, which is consistent with the previous literature. The results further suggest that accounting earnings are an important assessment indicator of expectations and uncertainty of future cash flows for Latin American firms. When we observed the investment model results, the accounting quality variable is negative and significant for all investment regression. In addition, the measure of accounting quality is a useful proxy to identity financial constraint, avoiding the problem associated with the ambiguity of investment-cash flow sensitivity.

The remainder of this paper is organized in five sections, including this introduction. Section 2 discusses the theoretical background and the research objective and provides a brief overview of the related research. Section 3 presents the data and the model specification. Section 4 describes the statistical summary and the econometric results. Section 5 provides the conclusions.

\section{LITERATURE REVIEW}

Although there are different methodologies to identify the situation of financial constraint, according to Whited (1992) firms in a situation of financial constraint are firms that presets difficult access to external financing. For Kaplan and Zingales (1997) a company is considered constrained if the costs 
or accessibility to external found are an obstacle to do new investments that it would have made if internal resources had been available. In this way, many theoretical developments related to financial constraints have highlighted the importance of sensibility of investment to cash flow. As largely stressed in the literature, since the study of Fazzari, Hubbard \& Petersen (1988), investment-cash flow sensibility as a proxy for financial constraint has been widely discussed. Fazzari, Hubbard \& Petersen (1988) estimated a fixed effects regression of investment as a function of cash flow and Tobin's Q, dividing a sample of firms into groups on the level of dividends distribution. Their results showed that firms with low-dividend pay exhibit high investment sensitivity to cash flow. According to their interpretation, the investments are sensitive to cash flow and the more financially constrained firms present greater investment-cash flow sensitivity than the least constrained ones.

However, this interpretation has received criticism, Kaplan \& Zingales (1997) questioned the relationship between cash flow and investment as an indicator of financial constraint. Using the same database as Fazzari, Hubbard \& Petersen (1988), Kaplan \& Zingales (1997) observed that this approach may provide little information about the presence of financial constraint. The authors investigated the relationship between investment and cash flow, considering the firms grouped by the degree of dividend distribution. They found that most of them could not be considered financially constrained. In other words, they did not find a strong theoretical reason for the investment-cash flow sensitivity to be a monotonic function of financial constraint.

Many studies have proposed a variety of ways to recognize the financially constrained firms. A common feature in the literature is to compare the cash-flow variable in different groups of firms to identify the financial constraint. In other words, if the cash-flow variable does not provide information on future profitability and the difference among the cash-flow coefficients for different groups of firms is statistically significant, then the investment-cash flow sensitivity is a useful proxy to indicate the presence of financial constraints.

Devereux \& Shiantarelli (1989) used the firms' characteristics, such as size and age, to split a sample of 720 U.K. firms into different groups, from 1969 to 1986. They found that cash-flow variables differ among firms. When firms are classified according to size, the cash flow plays a more important role for large firms than for small ones. According to the authors, a reason for this result is that large firms may have a more diverse ownership structure, which tends to increase agency costs. Hsiao \& Tahmiscioglu (1997) examined the presence of financial constraints on the investment decisions of 561 U.S. firms from 1971 to 1992. They used a mixed fixed - and random - coefficients framework to perform better than other common estimators for the panel data. From this framework, they found that the investment of more capital intensive firms were sensitive to fluctuations in internal funds. The authors argue that these firms require more capital for investment, have higher fixed costs, and tend to rely more on capital markets, whose characteristics better represent market imperfection. From the econometric point of view, the higher flexibility of the mixed model justifying their better goodness-of-fit which provides cross-level interactions effects between variables at different levels.

More recent, studies have focused on the financial constraint of firms' investment with negative cash flow (Allayannis \& Mozumdar, 2004, Bhagat, Moyen \& Suh, 2005, Cleary, Povel \& Raith, 2007). Allayannis \& Mozumbar (2004) found that constrained firms had significantly higher investment-cash flow sensitivity than the less constrained ones. Bhagat, Moyen \& Suh (2005) divided their sample into positive and negative operating incomes. The results showed that financially distressed firms with low 
cash flow had negative investment sensitivity to cash flow. Similarly, Cleary, Povel \& Raith (2007) found that firms with low cash flow were more likely to be financially constrained.

Although the literature provides discussions about the cash-flow approach as a measure of financial constraint, little is known about the effects of financial constraint and earning quality. In particular, both nationwide and international, it is important to investigate how the rising of earning quality may affect the investment-cash flow sensitivity.

\subsection{OVERVIEW OF THE EARNING QUALITY}

Over the last years an increasing number of papers, but still incipient, has analyzed the quality aspects of accounting information (Dechow \& Dichev, 2002, Dechow \& Schrand, 2004, Burgstaher, Hail \& Leuz, 2006, Barbosa, Scherer, Scarpin, \& Murcia, 2015, Potin, Bortolon \& Sarlo Neto, 2016). The main issue pointed out in several studies is the reliability level of financial information disclosed by firms. This concern has become more important over the last years, mainly after financial scandals with strong social consequences and harmful to the market.

The quality of accounting information is related to the information needs of users, shareholders and stakeholders. The investors are interested in knowing whether financial reports show the real financial conditions of firms, current and past situations, and if, based on available information in the reports, it is possible to predict future conditions and the firms' expectations. Considering these points Hendriksen \& Van Breda (1999) argued that accounting information should be objective, reliable and verifiable. Furthermore, it is important to take into account that, according to Financial Accounting Standards Board [Fasb] (1978), the principal objective of financial reports is to provide useful information for business decisions.

The quality of accounting information has received much attention in recent studies. Dechow \& Dichev (2002) proposed a model that has been cited and used by several researchers. In their paper, they propose a way to measure the quality of accounting information considering the accruals variation, measured by standard deviation of accruals quality. They affirmed that accruals have a direct relationship with cash, and that the errors in this connection are negatively related with the quality of accounting information. According to McNichols (2002), this model describes the relationship between accruals and cash flows and allows an empirical implementation of this relationship. Many studies have empirically employed this model to study the relationship between earnings quality and some economic aspects of firms (Francis, Lafond, Olsson \& Schipper, 2004, Aboody, Hughes \& Liu, 2005, Francis, Lafond, Olsson \& Schipper, 2005, Ball \& Shivakumar, 2006, Larcker, Richardson \& Tuna, 2007, Kim \& Qi, 2010, Dechow, Ge \& Schrand, 2010).

Antunes, Mendonça, Azevedo \& Alencar (2008) investigated the quality of accounting information of Brazilian companies before and after adhering to differentiated levels of corporative governance. Using three metrics for accounting information, the authors argue that the adhesion of segments from the Brazilian Stock Exchange does not imply that these companies have a better level of quality accounting information. Lima, Carvalho, Paulo \& Girão (2015) examined the relationship between life-cycle stages of companies listed on BM\&FBovespa regarding the quality of accounting information. The results suggest that there are significant differences in accounting quality in Brazilian companies' life-cycle stages. For Mazzioni, Prigol, Moura \& Klann (2016), who examined the influence of corporate governance and capital structure in the earnings management of public companies listed on the BM\&FBovesta (2010-2013), the influence of corporate governance to reduce earnings management was observed 
only in 2010. Additionally Costa \& Carvalho (2016) made a systematic review on the studies related to earnings management and corporate governance showed that most of the studies state that corporate governance reduces the earnings management. In this point of view is possible to affirm that the one of the objectives of corporate governance is to improve the quality of accounting information, which in general occurs, according to papers cited above.

Healy \& Wahlen (1999) showed that financial reporting and disclosure represent important information for management to communicate a firm's performance and governance to outside investors. Lambert, Leuz \& Verrecchia (2007) demonstrated that firms with high earnings quality associated to voluntary disclosure can obtain external resources with low cost. Francis, Lafond, Olsson \& Schipper (2005) showed that poor accruals quality may represent a risk information related to earnings and can be understood as a priced risk factor. On the other hand, Corea, Guay \& Verdi (2008), testing the accruals quality as a priced risk factor, found that there is no evidence that accruals quality is a priced risk factor. Other works, such as Francis, Lafond, Olsson \& Schipper (2004), Myers, Myers \& Omer (2003) and Bédard, Chtourou \& Courteau (2004), showed the relationship between economic characteristics of firms and proxies for accounting information quality, reflecting their economic importance.

Francis, Lafond, Olsson \& Schipper (2004), for instance, examined the relationship between cost of equity capital and seven attributes of earnings as quality of accruals. They found that firms with low values of each quality attribute presented higher costs of equity. Bédard, Chtourou and Courteau (2004) investigated whether the expertise, independence, and activities of a firm's audit committee has an effect on the quality of accounting reports. They examined the relationship between audit committee characteristics and earnings management. Measuring the level of earning and the abnormal accruals, they found that earnings management is negatively associated with the expertise and independence of audit committee members.

Biddle, Hilary \& Verdi (2009) provided evidence of association between financial reporting quality and investment for firms that operate in settings that are more prone to over-investment (under-investment). According to the authors the study suggests that firms with more high accounting quality are less susceptible to macroeconomic conditions, reducing the asymmetric information problem. Financial report quality is also related to investment efficiency, as showed by Biddle, Hilary and Verdi (2009), for whom higher financial report quality is related with the financial constraint on a firm's investment decision.

Mahmud, Ibrahim \& Pok (2009) analyzed whether the quality of earnings, measured by three attributes for earnings quality, is associated with a firm's performance. Their study showed that earnings quality has a positive relation with the performance of Malaysian listed firms, indicating information is useful for accounting information users and that earnings quality is an indirect way to measure the quality of financial reporting.

Studies considering the impact of accounting quality on a firm's performance are recent in developing countries and little explored in emergent economies. Antunes \& Costa (2007) studied the differences of the level quality of accounting information among Brazilian public companies and private companies that adhered to the New Market - higher level of corporate governance from Brazilian Stock Exchange. Employing three different proxies for accounting quality, the result shows that private companies which participate in the New Market presented better accounting information than public companies. The authors concluded that the accounting information of Brazilian public companies does not show the necessary characteristics to be used as an instrument of protection against the expropriation of public resources. 
Related the relationship between accruals quality and performance Costa, Lopes \& Costa (2006) investigated how earnings reported in the financial statements incorporate stock returns of public companies from Argentina, Brazil, Colombia, Peru and Venezuela. The results had shown a low relationship between current earnings and current stock returns.

As in prior studies, the high level of accounting quality can improve the firm's operational efficiency by reducing the conflict of interest between managers and shareholders and managers and investors. Therefore, the high quality of accounting information is expected to provide a positive impact on business performance. Thus within this context, this paper investigates whether Latin American companies using high-quality accounting information have a better performance.

\subsection{OVERVIEW OF EARNING QUALITY AND INVESTMENT}

Few studies have explored the relationship between earnings quality and debt financing. For Ghosh \& Moon (2010), earnings quality can be defined as the capacity of earnings to predict future cash flow.

Few studies have explored the relationship between quality of earnings and debt financing. And an important aspect to be mentioned is that managers of high debt firms have strong incentives to mask financial numbers using the accounting description. One possible explanation for this is that the managers are more likely to take risks just because they have no residual interest in the company. In addition, the covenants are frequently written in terms of accounting numbers and limit the role of managers and this may be associated to a limitation in the debt level or in definition of capital structure. Can it be plausible to expect that in firms with a high debt, the quality of earnings will be lower.

Carvalho, Kalatzis \& Albuquerque (2014) investigate whether the earnings quality of Latin American companies affects the probability of efficient investment decisions, over-investments, and the probability of under-investment. According to the authors the results indicate that poor earnings quality reduces the probability of efficient investment decisions and increases the probability of under-investment for Latin American firms.

The relationship between covenants and the manipulation of accrual was explored by Defond \& Jiambalvo (1994), which examined the accruals of firms that reported debt covenant violations in annual reports. The hypothesis adopted was that managers make accounting choices to increase the accounting earnings when their firms are close to debt covenant violation. The results, according to the researches, show substantial evidence that this hypothesis was true and the result was consistent with the theory proposed by Watts \& Zimmerman (1986), in which the high level of debt is a positive incentive for managers to make accounting choices as a way to avoid the covenants violation.

Aware of this Ghosh \& Moon (2010) investigate the relationship between corporate debt financing and earnings quality. The result of this research suggests a negative relation between debt and earnings quality when debt is sufficiently high and a positive relation for firms whose debt is low. In other words, the level of debt has a positive effect on the earnings quality at a low level and after that the impact is negative, promoting a reduction on earnings quality and a positive incentive of description decisions by managers. Thus, this study investigates whether Latin American companies with high-quality accounting information have a better performance and more investment opportunities. 


\section{DATA AND METHODOLOGY}

The sample consists of firms whose stocks are negotiated in Latin American stock markets from seven countries, namely, Argentina, Brazil, Colombia, Chile, Mexico, Peru and Venezuela. The data were obtained through the Economática ${ }^{\circledR}$ database, which provides and summarizes the financial information of companies. The sample included only non-financial companies, consistent with previous practices in the literature. The financial companies were removed from the sample because of their accounting peculiarities and because they are submitted to specific regulation. Our sample consists of 8,690 firm-year observations from 1989 to 2009. Table 1 present the distribution of firms by countries. Brazil and Chile represent more than $50 \%$ of the total sample.

Table 1: Number of companies per country present in the study

\begin{tabular}{|c|c|c|c|c|}
\hline \multirow{2}{*}{ Country } & \multicolumn{2}{|c|}{ Observations } & \multicolumn{2}{|c|}{ Firms } \\
\hline & $\mathrm{N}^{\circ}$ & $\%$ & $\mathrm{~N}^{\circ}$ & $\%$ \\
\hline Argentina & 827 & $10 \%$ & 59 & $10 \%$ \\
\hline Brazil & 2983 & $34 \%$ & 212 & $36 \%$ \\
\hline Chile & 1901 & $22 \%$ & 115 & $19 \%$ \\
\hline Colombia & 178 & $2 \%$ & 16 & $3 \%$ \\
\hline Mexico & 1341 & $15 \%$ & 88 & $15 \%$ \\
\hline Peru & 1249 & $14 \%$ & 90 & $15 \%$ \\
\hline Venezuela & 211 & $2 \%$ & 16 & $3 \%$ \\
\hline Total & 8690 & $100 \%$ & 596 & $100 \%$ \\
\hline
\end{tabular}

Characteristics such as the firm's size, leverage and sales growth were also considered in the model of this work. According to Gu, Lee \& Rosett (2005), these variables are related to the variability of accrual and could also be related to economies of scale, scope and industry structure. Although the leverage effects can be beneficial to performance, they also increase the risk of firms, which needs to be considered in the relationship analysis of performance and some aspects of the firms, such as size, leverage, sales growth and so on. The variable sales growth is used in this work as a control variable, represented by change in revenues. This variable normally affects the accruals and may influence the market performance and future expectations about the companies (Dechow \& Sloan, 1991, Penman \& Zhang, 1999).To measure the quality of accounting information, we used five proxies, which are represented by accruals quality, feedback value, predictive value, absolute abnormal accruals and one variable that was constructed with a common factor score obtained from the other four variables. The accruals quality was proposed by Dechow and Dichev (2002) with changes suggested by McNichols (2002) and the same methodology adopted by Francis, Nanda \& Olsson (2008). To capture the quality of accounting information, we used the model (1) as suggested by Francis, Nanda \& Olsson (2008). Therefore, to capture the standard deviation residual accrual quality of the firm, we estimated the following model:

$$
\frac{\operatorname{TCA}_{j, t}}{\text { Assets }_{j, t}}=\phi_{0, t}+\phi_{1, t} \frac{\mathrm{CFO}_{j, t-1}}{\text { Assets }_{j, t-1}}+\phi_{2, t} \frac{\mathrm{CFO}_{j, t}}{\text { Assets }_{j, t}}+\phi_{3, t} \frac{\mathrm{CFO}_{j, t}+1}{\text { Assets }_{j, t}+1}+\phi_{4, t} \frac{\Delta \operatorname{Rev}_{j, t}}{\text { Assets }_{j, t}}+\phi_{5, t} \frac{P P E_{j, t}}{\text { Assets }_{j, t}}+v_{j, t}
$$


where $\mathrm{TCA}_{\mathrm{j}, \mathrm{t}}$ is the current Accruals defined as $\mathrm{TCA}_{\mathrm{j}, \mathrm{t}}=\mathrm{CA}_{\mathrm{j}, \mathrm{t}}-\Delta \mathrm{CL}_{\mathrm{j}, \mathrm{t}}-\Delta \mathrm{Cash}_{\mathrm{j}, \mathrm{t}}+\Delta \mathrm{Stdebt}_{\mathrm{j}, \mathrm{t}} \mathrm{t}$ is the year, ranging from 1 to $\mathrm{T}, \mathrm{j}$ is the firm, ranging from 1 to $\mathrm{N}, \Delta \mathrm{CA}_{\mathrm{j}, \mathrm{t}}$ is change in the current asset, $\Delta \mathrm{CL}_{\mathrm{j}, \mathrm{t}}$ is change in current liabilities, $\Delta$ Cash $_{\mathrm{j}, \mathrm{t}}$ is change in cash, $\Delta$ Stdebt $_{\mathrm{j}, \mathrm{t}}$ is change in current debt, Assets $_{\mathrm{j}, \mathrm{t}}$ is total asset, $\mathrm{CFO}_{\mathrm{j}, \mathrm{t}}$ is operational cash flow measured as $\mathrm{CFO}_{\mathrm{j}, \mathrm{t}}=\mathrm{Nibe}_{\mathrm{j}, \mathrm{t}}-\mathrm{TA}_{\mathrm{j}, \mathrm{t}} \mathrm{Nibe}_{\mathrm{j}, \mathrm{t}}$ is change in net income before extraordinary items, $\mathrm{TA}_{\mathrm{j}, \mathrm{t}}$ is total Accrual measured as $\Delta \mathrm{CA}_{\mathrm{j}, \mathrm{t}}-\Delta \mathrm{CL}_{\mathrm{j}, \mathrm{t}}-\Delta \mathrm{Cash}_{\mathrm{j}, \mathrm{t}}+\Delta$ Stdebt $_{\mathrm{j}, \mathrm{t}}-$ Dep $_{\mathrm{j}, \mathrm{t}^{\mathrm{t}}}$ Dep $_{\mathrm{j}, \mathrm{t}}$ is depreciation and amortization expenses, $\Delta$ Rev $_{\mathrm{j}, \mathrm{t}}$ is change in revenues, $\mathrm{PPE}_{\mathrm{j}, \mathrm{t}}$ is value of property, plant and equipment.

The next step is to estimate the predicted value of earnings, which is measured by the ability to calculate future earnings (Mahmud, Ibrahim \& Pok, 2009).

$$
\text { Earns }_{j . t+1}=\alpha_{0}+\beta_{1} C F O_{j, t}+\beta_{2} T A_{j, t}+\theta_{j t}
$$

where Earns $\mathrm{j}_{\mathrm{j}, \mathrm{t}+1}$ is net earnings in the next year, $\theta_{\mathrm{j}, \mathrm{t}}$ is the residual, $\mathrm{t}$ is the year, ranging from 1 to $T, \mathrm{j}$ is the firm, ranging from 1 to $N$. The residual value is measured in module $\left(\left|\theta_{\mathrm{j}, \mathrm{t}}\right|\right)$ and is used as a measure of earnings predictive ability. If this value is low the operational cash flow and the total accrual is a good measure for future earnings, indicating high-quality of accounting information.

The third stage used to measure the quality of accounting information is the feedback value of firms, employed by Kormendi \& Lipe (1987) and Mahmud, Ibrahim \& Pok (2009). The feedback value variable was constructed in three steps. In the first step we obtained the residual from the regression of earnings in $\mathrm{t}+1$ against earnings in $\mathrm{t}$. In the second step the residual was obtained by the regression of earnings in $t+1$ against earnings in $t-1$. The idea is to measure the role of current earnings due to a change on earnings prediction for the next year (Barua, 2005). The feedback value of earnings was measures as:

$$
F V_{j, t}=\omega_{j, t+1}-\lambda_{j, t+1}
$$

where $\mathrm{FVj}, \mathrm{t}$ is the feedback value, $\mathrm{t}$ is the year, ranging from 1 to $\mathrm{T}, \mathrm{j}$ is the firm, ranging from 1 to $\mathrm{N}$, $\omega_{j, t+1}$ and $\lambda_{j, t+1}$ are the residuals described in the first and second steps, respectively.

The fourth model estimated herein is a modified version of that proposed by Jones (1991). In expression 4 we estimated the parameters of the absolute value of abnormal accrual by industry.

$$
\frac{T A_{j, t}}{\text { Asset }_{j, t-1}}=\gamma_{1 i} \frac{1}{\text { Asset }_{j, t-1}}+\gamma_{2 i} \frac{\Delta \operatorname{Re} v_{j, t}}{\text { Asset }_{j, t-1}}+\gamma_{3 i} \frac{P P E_{j, t}}{\text { Asset }_{j, t-1}}+\varepsilon_{j, t}
$$

where $\mathrm{TA}_{\mathrm{j}, \mathrm{t}}$ is the total accruals, $t$ is the year, ranging from 1 to $T, j$ is the firm, ranging from 1 to $\mathrm{N}, \mathrm{i}$ is the industry index, limited to at least 20 firms for each sector, Asset ${ }_{\mathrm{j}, \mathrm{t}}$ is the total of assets, $\Delta \operatorname{Rev}_{\mathrm{j}, \mathrm{t}}$ is variation in revenues, and $\mathrm{PPE}_{\mathrm{j}, \mathrm{t}}$ is the capital stock.

The coefficients of expression (4) were estimated to calculate the normal accrual, as follows by equation (5).

$$
N A_{j, t}=\hat{\gamma}_{1} \frac{1}{\text { Asset }_{j, t-1}}+\hat{\gamma}_{2} \frac{\left(\Delta \operatorname{Re} v_{j, t}-\Delta A R_{j, t}\right)}{\text { Asset }_{j, t-1}}+\hat{\gamma}_{3} \frac{P P E_{j, t}}{\text { Asset }_{j, t-1}}
$$

where $\Delta A R_{j, t}$ is the change in accounting receivable between years $t$ and $t-1$ of firm $\mathrm{j}$. Once calculated the normal accruals we obtained the abnormal accruals, given by: 


$$
A A_{j t}=\frac{T A_{j, t}}{\operatorname{Asset}_{j t-1}}-N A_{j, t}
$$

The absolute value of equation $6\left(\mid \mathrm{AA}_{\mathrm{j}, \mathrm{t}}\right)$ is the metrics to abnormal accruals (Francis, Nanda \& Olsson, 2008). The value of absolute abnormal accrual was our fourth proxy for earnings quality.

Finally, to construct our fifth variable we used the factor analysis with the objective to reduce the four proxies presented above to only one variable. The Accruals Quality Factor (AQF) was our last proxy for earnings quality and is a common factor score obtained from a factor analysis of Predict Value, Feedback Value, Absolute Abnormal Accrual and Accrual Quality.

In order to test whether there is a positive and significant relation between proxies for earnings quality and performance we estimated the following model:

$$
\operatorname{Perf}_{j, t}=\alpha_{j}+\beta_{1} \text { EarnQual }_{j t}+\beta_{2} \text { Size }_{j, t}+\beta_{3} \text { Lev }_{j, t}+\beta_{4} \text { Growth }_{j, t}+\varepsilon_{j, t}
$$

where Perf ${ }_{j, t}$ is measured by the use of variables return on equity (ROE) or Market to Book (MB). The $\mathrm{ROE}$ is calculated by the division of earning by equity and $\mathrm{MB}$ is calculated by division of market value of equity by accounting value of equity, $a_{j}$ is the firm specific effect, EarnQual ${ }_{j, t}$ is a metric for earnings quality measured by accruals quality (AA), predictive value (PV), feedback value (FV), absolute abnormal accrual (AAA) or accrual quality factor (AQF) calculated in the steps above, and control variables given by size, leverage and growth.

To analyze the relationship between quality of accrual and investment decision we include the variable Accrual Quality Factor into the model proposed by Jorgenson (1963), which resumes the four proxies for quality of accounting information presented above. In this case, the purpose is to measure the impact of the earnings quality in the investment. According to the contractual theory of firms, the function of accounting is to reduce the asymmetric information between agents and stakeholders. Therefore, it is expected that the increase of accounting information quality should improve the access of external funds, and consequently, represent a positive impact on investment. The "earnings quality refers to the ability of earnings to predict future cash flow" (Ghosh \& Moon, 2010) and it should be able to capture the effect of financial constraints on corporate investments decisions. We estimated the following model:

$$
\left(\frac{I}{K}\right)_{j, t}=\alpha_{j}+\omega_{q}+\varphi_{i}+\beta_{1}\left(\frac{I}{K}\right)_{j, t-1}+\beta_{2}\left(\frac{I}{K}\right)_{j, t-1}^{2}+\beta_{3}\left(\frac{S}{K}\right)_{j, t-1}+\beta_{4}\left(\frac{C F}{K}\right)_{j, t-1}+\beta_{5}\left(\frac{D}{K}\right)_{j, t-1}+\beta_{6} A Q F_{j, t}+\varepsilon_{j . t}
$$

where $j$ represents the firm, $t$ represents time, a refers to unobserved firm-specific effect, $\omega$ refers to time-effect, $\varphi$ refers to country-specific effect ${ }^{2}, I$ is the investment rate of firm, $S$ is the sale, $D$ is the financing, $C F$ is the cash-flow variable, AQF is a factor that resumes the proxies for earnings quality Predictive Value, Feedback Value, Absolute Abnormal Accrual and Quality of accrual.

In this study, the investment model coefficients are estimated using the fixed-effect (FE) and mixed model. The fixed-effect model is applied due to the existence of a correlation between the firm-specific effect and some regressor ${ }^{3}$. However, in the investment model we also confront the endogeneity problem, which appears in the presence of the lagged dependent variable as an independent variable. The usual approach, when facing the problem of endogenous regressor, is to use the IV estimator. Although 2 Besides introducing a firm-specific effect and time effect, we also used a country-specific effect aiming at controlling the unobserved characteristics. This could control information on the macroeconomic conditions of Latin American firms' decisions.

3 Hausman test confirmed the existence of correlation between firm-specific effect with some regressors, hence the test results $x^{2}=814.16$ and Prob. $=0.000$. 
the conventional IV approach provides an efficient estimation, we question the validity of this application. FE and IV estimator do not allow incorporating an additional randomness on explanatory variables in order to capture the unobserved heterogeneity of the cross section units, as the mixed model allows us to do. Although few papers have used the mixed model, mainly in the analysis of investment decisions, we used it in our approach. We believe that the mixed model may offer a number of advantages, such as: increase in the flexibility of model specification and better specification of the uncertainty.

Using the notation in Lindstrom and Bates (1988) the mixed model can present different slopes and intercepts for the levels. For individuals in group 1:

$$
y_{i j}=\left(\beta_{1}+b_{i 1}\right)+\left(\beta_{2}+b_{i 2}\right) x_{i j}+e_{i j}
$$

And for individuals

$$
y_{i j}=\left(\beta_{3}+b_{i 1}\right)+\left(\beta_{4}+b_{i 2}\right) x_{i j}+e_{i j}
$$

where $y$ is the response vector for subject $i, \beta$ is the vector of parameters for the fixed effect with dimension $p \times 1$ (where $p$ is the number of parameters for the fixed effect), $b_{i}$ is the vector of parameters for the random effect with dimension $q \times 1$ (where $q$ is the number of parameters for the random effect). The distribution of the random effects is assumed to be $\mathrm{N}\left(0, \sigma^{2} \mathrm{D}\right)$. Both error and random effect are assumed to be independent and normally distributed with zero mean and covariance matrices $N\left(0, \sigma^{2}\right.$ I) and $\sigma^{2} D$, respectively ${ }^{4}$.

In this paper, the mixed-effects model is used, as it allows a mixture of fixed-and random-effects. Here the regressions consider the firm-specific effect and time-effect as fixed effects, and the explanatory variables as randomly distributed. The consequence of having random effects introduces a wide flexibility for modeling complex error structures into the regression, hence providing this application with a better performance than other common estimators for panel data. As Weinhold (1999) pointed out, the heterogeneity on the lagged dependent variable across the subjects can lead to bias when ignored. In other words, a model that allows considering the heterogeneity in the parameters and avoiding this bias is more appropriate than the traditional model.

In addition, we use the KZ index to reflect the firms' financial constraint. This should help to identify whether the quality of financial reporting is associated with investment classified by not constrained and constrained firms. The advantage of the KZ index used in this paper is that it separated the firms' characteristics associated with external financial constraint. We still used four different proxies for accounting information quality.

The KZ index, which is based on the results in Kaplan \& Zingales (1997), is obtained from a model that contain variables associated with financial constraint such as cash flow, leverage, Tobin's $Q$, cash levels and dividends (Lamont, Polk \& Saá-Requejo, 2001). Although to construct the KZ index we do not use the dividend variable due to unavailability of information in the database, we believe that the $\mathrm{KZ}$ index obtained is a useful proxy to identify the financially constrained firms. The KZ index can be expressed as:

$$
\text { KZindex }=-(1.0019 \times \text { CashFlow })+(0.2826 \times Q)+(3.1391 \times \text { Leverage })-(1.3147 \times \text { CashHolding })(10)
$$

Firms are classified by the tercile of the $\mathrm{KZ}$ index in order to identity the unconstrained and constrained firms. The firms that presented a great $K Z$ index are classified as financially constrained, and firms with low KZ index are classified as financially unconstrained.

4 We check the normality of residuals using pnorm, qnorm, kdensity (software Stata ${ }^{\circledR}$ ), and other statistics skewness/kurtosis tests for Normality, and we don't reject the hypothesis of normality of the residuals. 


\section{FINDINGS}

This section reports the main economic results obtained by considering the five proxies for earnings quality on the firm's performance and the impact of the earnings quality on financial investment decisions. Table 2 shows the mean values of performance, earnings quality and control variables by country.

The mean ROE was of $-6 \%$ for Argentina and $-16 \%$ for Brazil, while Tobin's Q was 0.56 and 0.85 for both countries, showing that the performance of Latin American firms was low in the period of this study. The firm's low values performance can be explained by the successive recessions during the analyzed period, increasing the debt cost with a strong negative impact on the firms' performance (cambial shock in 1999). The period between 2001 and 2002 was the apex of the Argentinean crisis and difficult years for Latin America companies, which is reflected in descriptive statistics. The firm's best performance is for Chile and Mexico, with a profitability of $8 \%$ and $7 \%$ in the period, respectively.

Table 2: Descriptive statistics: mean and standard deviation

\begin{tabular}{|c|c|c|c|c|c|c|c|}
\hline & Argentina & Brazil & Chile & Colombia & Mexico & Peru & Venezuela \\
\hline ROE & $\begin{array}{l}-0.06 \\
(1.09)\end{array}$ & $\begin{array}{c}-0.16 \\
(3.26)\end{array}$ & $\begin{array}{c}0.08 \\
(0.32)\end{array}$ & $\begin{array}{c}0.06 \\
(0.22)\end{array}$ & $\begin{array}{c}0.07 \\
(0.37)\end{array}$ & $\begin{array}{c}0.06 \\
(0.36)\end{array}$ & $\begin{array}{c}0.05 \\
(0.17)\end{array}$ \\
\hline TQ & $\begin{array}{c}0.56 \\
(3.77)\end{array}$ & $\begin{array}{c}0.85 \\
(13.48)\end{array}$ & $\begin{array}{c}0.85 \\
(3.28)\end{array}$ & $\begin{array}{c}0.55 \\
(0.79)\end{array}$ & $\begin{array}{c}0.59 \\
(1.56)\end{array}$ & $\begin{array}{c}0.79 \\
(3.18)\end{array}$ & $\begin{array}{c}0.33 \\
(0.54)\end{array}$ \\
\hline$A Q$ & $\begin{array}{l}0.11 \\
(0.1)\end{array}$ & $\begin{array}{c}0.11 \\
(0.15)\end{array}$ & $\begin{array}{c}0.11 \\
(0.15)\end{array}$ & $\begin{array}{c}0.1 \\
(0.07)\end{array}$ & $\begin{array}{c}0.11 \\
(0.09)\end{array}$ & $\begin{array}{c}0.1 \\
(0.07)\end{array}$ & $\begin{array}{c}0.09 \\
(0.06)\end{array}$ \\
\hline PV & $\begin{array}{l}11.63 \\
(8.15)\end{array}$ & $\begin{array}{c}12.56 \\
(11.27)\end{array}$ & $\begin{array}{l}10.19 \\
(12.3)\end{array}$ & $\begin{array}{c}14.36 \\
(15.67)\end{array}$ & $\begin{array}{c}9.05 \\
(8.21)\end{array}$ & $\begin{array}{c}14.91 \\
(16.42)\end{array}$ & $\begin{array}{l}13.01 \\
(7.75)\end{array}$ \\
\hline FV & $\begin{array}{c}0.98 \\
(0.07)\end{array}$ & $\begin{array}{c}0.99 \\
(0.07)\end{array}$ & $\begin{array}{c}1.01 \\
(0.11)\end{array}$ & $\begin{array}{c}1.09 \\
(1.17)\end{array}$ & $\begin{array}{c}1 \\
(0.08)\end{array}$ & $\begin{array}{c}1.01 \\
(0.07)\end{array}$ & $\begin{array}{c}0.99 \\
(0.06)\end{array}$ \\
\hline AAA & $\begin{array}{c}0.3 \\
(0.3)\end{array}$ & $\begin{array}{c}0.73 \\
(25.12)\end{array}$ & $\begin{array}{c}0.32 \\
(0.37)\end{array}$ & $\begin{array}{c}1.51 \\
(16.02)\end{array}$ & $\begin{array}{c}0.32 \\
(0.33)\end{array}$ & $\begin{array}{c}0.32 \\
(0.36)\end{array}$ & $\begin{array}{l}0.27 \\
(0.3)\end{array}$ \\
\hline IQF & $\begin{array}{c}0.03 \\
(0.39)\end{array}$ & $\begin{array}{l}0.04 \\
(0.5)\end{array}$ & -0.07 & $\begin{array}{l}-0.06 \\
(1.71)\end{array}$ & $\begin{array}{l}-0.09 \\
(0.35)\end{array}$ & $\begin{array}{c}0.05 \\
(0.49)\end{array}$ & $\begin{array}{c}0.01 \\
(0.26)\end{array}$ \\
\hline Size & $\begin{array}{c}9.80 \mathrm{E}+05 \\
(2.20 \mathrm{E}+06)\end{array}$ & $\begin{array}{c}2.40 \mathrm{E}+06 \\
(9.10 \mathrm{E}+06)\end{array}$ & $\begin{array}{c}7.80 \mathrm{E}+05 \\
(2.20 \mathrm{E}+06)\end{array}$ & $\begin{array}{c}7.40 \mathrm{E}+05 \\
(9.20 \mathrm{E}+05)\end{array}$ & $\begin{array}{c}2.70 \mathrm{E}+06 \\
(7.80 \mathrm{E}+06)\end{array}$ & $\begin{array}{c}2.50 E+05 \\
(4.70 E+05)\end{array}$ & $\begin{array}{c}9.70 \mathrm{E}+05 \\
(1.50 \mathrm{E}+06)\end{array}$ \\
\hline Lev & $\begin{array}{c}3.09 \\
(30.99)\end{array}$ & $\begin{array}{c}1.9 \\
(40.62)\end{array}$ & $\begin{array}{c}2.05 \\
(1.94)\end{array}$ & $\begin{array}{l}1.76 \\
(0.6)\end{array}$ & $\begin{array}{c}1.5 \\
(28.52)\end{array}$ & $\begin{array}{c}2.15 \\
(2.37)\end{array}$ & $\begin{array}{c}2.1 \\
(8.2)\end{array}$ \\
\hline Growth & $\begin{array}{c}0.42 \\
(4.16)\end{array}$ & $\begin{array}{c}0.16 \\
(0.65)\end{array}$ & $\begin{array}{c}0.14 \\
(0.62)\end{array}$ & $\begin{array}{c}0.09 \\
(0.69)\end{array}$ & $\begin{array}{c}0.43 \\
(10.69)\end{array}$ & $\begin{array}{c}0.15 \\
(0.48)\end{array}$ & $\begin{array}{c}0.32 \\
(1.16)\end{array}$ \\
\hline
\end{tabular}

$R O E$ is Return on equity, TQ is the Tobin's $Q$ ratio, AQ is the Accruals Quality, PV is Predictive Value, FV is the Feedback Value, AAA is Absolute Abnormal Accruals, Lev is the Leverage, Size is the size of the firm in thousands of U.S. dollars. Standard deviations are between parentheses.

If we analyze the annual performance for the two dependent variables and the standard deviation, it is possible to note that Latin American firms present a high variability in their performance, mainly for Brazilian and Argentinean companies. The mean values of Accrual Quality and Feedback Value variables practically do not differ among countries. For the Predict Value variable, the higher mean value is of 14.91 for Peru and the lower value is of 9.05 for Mexico. The values of this variable indicate that the higher the value, the worse the quality of accounting information. When we consider the Absolute Abnormal Accruals variable as a measure of accounting quality, the country that presents the worst indicator is Brazil. We can observe in Table 2, that the descriptive data of the countries with better accounting information are Chile and Mexico, it presented the lowest value for Information Quality Factor. The countries with the largest firms are Brazil and Mexico, respectively, while the smallest firms are in Peru. The firms with more leverage are from Argentina, while the lowest leverage is from Mexico. On the other hand, firms with more sales growth are in Argentina and lower sales are for the Colombian firms.

The first hypothesis explored in this paper is that there is a positive relationship between higher-quality financial information and performance. Five proxies were constructed to evaluate the quality of accounting information, which were structured by longitudinal data and regressed to test the hypothesis 
that higher-quality financial information is positively and significantly associated with performance. We tested ten models and five of these models refer to the regression of the Return on equity against the quality accounting variables and the other five refer to Market to book with the same quality financial variables. In the ten models we also included control variables as explanatory. The results of the estimations of ten models are presented in Table 3.

The size variable, measured by the natural logarithm of total asset, is positive and significant with Return on Equity for all firms except for the group formed by unconstrained firms, indicating that the increase in firm size leads to an improvement in operating performance, but for unconstrained firms, the size is not significant enough to explain the operational performance. According to Titman \& Wessels (1988) larger firms have the potential to easily access funds and small firms have more financial constraints and greater difficulty in accessing credit, as well as higher financing costs (Whited, 1992, Fazzari \& Petersen, 1993, Ozkan \& Ozkan, 2004). In relation to investment opportunities, the size was not significant to explain Market to book for constrained firms, but for the others, size improves the investment opportunities. According to Himmelberg, Hubbard \& Palia (1999), large firms are more likely to enjoy market power and scale economies, nonetheless they are subject to greater monitoring and agency costs, but according to our results the size cannot improve the investment opportunity.

The leverage variable was negative and significant to explain the return on equity for constrained firms, while it was positive and significant for other groups of firms. The negative sign indicates that an increase in leverage reduces the firm's operational performance, probably due to cost debt that is captured by return on equity mainly for constrained firms. In relation to Market to book this variable was not significant in any model.

The sales growth was significant for all models that use Return on Equity as a dependent variable and Market to book. The significance of the sales growth variable indicates that the increase in sales improves the performance, both operationally and market performance. Therefore, sales growth potentially and effectively represents the expectation of future earnings as future investment opportunities.

The Accrual Quality is significant only for Return on equity for constrained firms. In relation to Market to book (model VI), this variable was not significant for any group of firms. This result indicates that high values of the Accruals Quality have a negative impact on the performance of constrained firms, i. e., high level of earnings quality is related positively with performance for financially constrained firms. The accruals idea refers to the revenue and expenses that are not received or paid out, which reflect on earnings. Accrual estimates can often be imprecise or erroneous and not often done, reducing the earnings quality. Therefore, the higher the value of the Accruals Quality metric, the worse the earnings quality will be and, consequently, the worse the financial reporting quality.

For the Predictive Value variable we found a significant and positive relationship with the firms' investment opportunities for all groups of firms and using the Return on Equity as a dependent variable. This variable is negative and significant only for constrained firms. The negative sign for Predictive Value was expected, given that the higher the predictive value error, the lower the quality of accounting information will be. Moreover, it was expected that the impact of this variable on performance would be negative, because it was expected that better accounting information would provide an improvement for managers monitoring. This opposite result for other models can explain this by considering that a firm's market value and its operational performance are influenced more by other aspects, such as growth in sales, rather than by accounting information quality. 
Table 3: Mixed Models by using ROE and Market to book

\begin{tabular}{|c|c|c|c|c|c|c|c|c|c|c|}
\hline \multirow{3}{*}{ Variables } & \multicolumn{10}{|c|}{ Firms with low degree of financial constraint } \\
\hline & \multicolumn{5}{|c|}{ Return on equity } & \multicolumn{5}{|c|}{ Market to book } \\
\hline & Model 1 & Model 2 & Model 3 & Model 4 & Model 5 & Model 6 & Model 7 & Model 8 & Model 9 & Model 10 \\
\hline Size & $\begin{array}{c}0.002 \\
(0.005)\end{array}$ & $\begin{array}{c}0.003 \\
(0.005)\end{array}$ & $\begin{array}{r}-0.0001 \\
(0.005)\end{array}$ & $\begin{array}{c}0.001 \\
(0.005)\end{array}$ & $\begin{array}{c}0.001 \\
(0.005)\end{array}$ & $\begin{array}{c}0.176^{* * *} \\
(0.029)\end{array}$ & $\begin{array}{c}0.187^{* * * *} \\
(0.028)\end{array}$ & $\begin{array}{c}0.172^{* * *} \\
(0.029)\end{array}$ & $\begin{array}{c}0.186^{* * *} \\
(0.029)\end{array}$ & $\begin{array}{c}0.184^{* * *} \\
(0.029)\end{array}$ \\
\hline Lev & $\begin{array}{c}0.031^{* * *} \\
(0.008)\end{array}$ & $\begin{array}{c}0.032^{* * *} \\
(0.008)\end{array}$ & $\begin{array}{c}0.029^{* * *} \\
(0.009)\end{array}$ & $\begin{array}{c}0.032^{* * *} \\
(0.008)\end{array}$ & $\begin{array}{c}0.031 * * * \\
(0.009)\end{array}$ & $\begin{array}{l}-0.006 \\
(0.006)\end{array}$ & $\begin{array}{l}-0.006 \\
(0.005)\end{array}$ & $\begin{array}{l}-0.006 \\
(0.006)\end{array}$ & $\begin{array}{l}-0.006 \\
(0.006)\end{array}$ & $\begin{array}{l}-0.006 \\
(0.005)\end{array}$ \\
\hline Growth & $\begin{array}{c}0.058^{* * *} \\
(0.010)\end{array}$ & $\begin{array}{l}-0.006 \\
(0.005)\end{array}$ & $\begin{array}{l}-0.006 \\
(0.005)\end{array}$ & $\begin{array}{l}-0.006 \\
(0.005)\end{array}$ & $\begin{array}{l}-0.006 \\
(0.005)\end{array}$ & $\begin{array}{l}-0.006 \\
(0.005)\end{array}$ & $\begin{array}{l}-0.006 \\
(0.005)\end{array}$ & $\begin{array}{l}-0.006 \\
(0.005)\end{array}$ & $\begin{array}{l}-0.006 \\
(0.005)\end{array}$ & $\begin{array}{l}-0.006 \\
(0.005)\end{array}$ \\
\hline$A Q$ & $\begin{array}{l}-0.125 \\
(0.151)\end{array}$ & & & & & $\begin{array}{l}-1.069 \\
(0.702)\end{array}$ & & & & \\
\hline PV & & $\begin{array}{c}0.0006 \\
(0.0004)\end{array}$ & & & & & $\begin{array}{c}0.009^{* * *} \\
(0.002)\end{array}$ & & & \\
\hline FV & & & $\begin{array}{c}1.654^{* * *} \\
(0.075)\end{array}$ & & & & & $\begin{array}{c}2.266^{* * *} \\
(0.379)\end{array}$ & & \\
\hline AAA & & & & $\begin{array}{c}-0.033^{* * *} \\
(0.016)\end{array}$ & & & & & $\begin{array}{c}0.309^{* * * *} \\
(0.079)\end{array}$ & \\
\hline IQF & & & & & $\begin{array}{c}-0.037^{* * *} \\
(0.014)\end{array}$ & & & & & $\begin{array}{c}0.156^{* * *} \\
(0.069)\end{array}$ \\
\hline Cons & $\begin{array}{c}0.100 \\
(0.100)\end{array}$ & $\begin{array}{c}0.001 \\
(0.098)\end{array}$ & $\begin{array}{c}-1.613^{* * *} \\
(0.121)\end{array}$ & $\begin{array}{c}0.050 \\
(0.103)\end{array}$ & $\begin{array}{c}0.106 \\
(0.098)\end{array}$ & $\begin{array}{c}-1.954^{* * *} \\
(0.523)\end{array}$ & $\begin{array}{c}-2.194^{* * *} \\
(0.449)\end{array}$ & $\begin{array}{c}-4.406 * * * \\
(0.638)\end{array}$ & $\begin{array}{c}-2.121^{* * *} \\
(0.475)\end{array}$ & $\begin{array}{c}-2.159^{* * *} \\
(0.518)\end{array}$ \\
\hline \multirow[t]{2}{*}{$\begin{array}{l}\sigma^{2} \\
\text { Obs. }\end{array}$} & $\begin{array}{l}0.151 \\
1809\end{array}$ & $\begin{array}{l}0.151 \\
1806\end{array}$ & $\begin{array}{l}0.127 \\
1809\end{array}$ & $\begin{array}{l}0.151 \\
1809\end{array}$ & $\begin{array}{l}0.150 \\
1806\end{array}$ & $\begin{array}{l}0.714 \\
1809\end{array}$ & $\begin{array}{l}0.713 \\
1806\end{array}$ & $\begin{array}{l}0.709 \\
1809\end{array}$ & $\begin{array}{l}0.711 \\
1809\end{array}$ & $\begin{array}{l}0.714 \\
1806\end{array}$ \\
\hline & \multicolumn{10}{|c|}{ Firms with intermediate financial situation } \\
\hline Size & $\begin{array}{l}0.006^{* *} \\
(0.002)\end{array}$ & $\begin{array}{l}0.006^{* *} \\
(0.002)\end{array}$ & $\begin{array}{l}0.003^{* *} \\
(0.001)\end{array}$ & $\begin{array}{l}0.006^{* *} \\
(0.002)\end{array}$ & $\begin{array}{l}0.004^{*} \\
(0.002)\end{array}$ & $\begin{array}{c}0.050^{* * * *} \\
(0.014)\end{array}$ & $\begin{array}{c}0.059^{* * * *} \\
(0.014)\end{array}$ & $\begin{array}{c}0.049^{* * *} \\
(0.013)\end{array}$ & $\begin{array}{c}0.056^{* * * *} \\
(0.015)\end{array}$ & $\begin{array}{c}0.057^{* * *} \\
(0.014)\end{array}$ \\
\hline Lev & $\begin{array}{c}0.009^{* * *} \\
(0.002)\end{array}$ & $\begin{array}{c}0.009^{* * *} \\
(0.002)\end{array}$ & $\begin{array}{c}0.007^{* * *} \\
(0.001)\end{array}$ & $\begin{array}{c}0.009^{* * *} \\
(0.002)\end{array}$ & $\begin{array}{c}0.009 * * * \\
(0.002)\end{array}$ & $\begin{array}{r}-0.0005 \\
(0.002)\end{array}$ & $\begin{array}{l}-0.0008 \\
(0.002)\end{array}$ & $\begin{array}{l}-0.001 \\
(0.002)\end{array}$ & $\begin{array}{l}-0.0003 \\
(0.002)\end{array}$ & $\begin{array}{c}0.0005 \\
(0.0006)\end{array}$ \\
\hline Growth & $\begin{array}{c}0.083^{* * *} \\
(0.009)\end{array}$ & $\begin{array}{c}0.083^{* * *} \\
(0.009)\end{array}$ & $\begin{array}{c}0.018^{* * *} \\
(0.006)\end{array}$ & $\begin{array}{c}0.082^{* * *} \\
(0.009)\end{array}$ & $\begin{array}{c}0.074^{* * *} \\
(0.009)\end{array}$ & $\begin{array}{c}0.410^{* * * *} \\
(0.051)\end{array}$ & $\begin{array}{c}0.433^{* * *} \\
(0.050)\end{array}$ & $\begin{array}{c}0.305^{* * *} \\
(0.052)\end{array}$ & $\begin{array}{c}0.375^{* * *} \\
(0.052)\end{array}$ & $\begin{array}{c}0.424^{* * *} \\
(0.050)\end{array}$ \\
\hline$A Q$ & $\begin{array}{l}-0.103 \\
(0.091)\end{array}$ & & & & & $\begin{array}{l}-0.328 \\
(0.439)\end{array}$ & & & & \\
\hline PV & & $\begin{array}{c}-0.0003 \\
(0.0002)\end{array}$ & & & & & $\begin{array}{c}0.011 * * * \\
(0.001)\end{array}$ & & & \\
\hline FV & & & $\begin{array}{c}2.112^{* * *} \\
(0.032)\end{array}$ & & & & & $\begin{array}{c}3.162^{* * *} \\
(0.193)\end{array}$ & & \\
\hline AAA & & & & $\begin{array}{c}0.007 \\
(0.012)\end{array}$ & & & & & $\begin{array}{c}0.240^{* * * *} \\
(0.059)\end{array}$ & \\
\hline IQF & & & & & $\begin{array}{c}-0.093^{* * *} \\
(0.007)\end{array}$ & & & & & $\begin{array}{c}0.149 * * * \\
(0.032)\end{array}$ \\
\hline Cons & $\begin{array}{l}-0.058 \\
(0.044)\end{array}$ & $\begin{array}{l}-0.063 \\
(0.044)\end{array}$ & $\begin{array}{c}-2.121^{* * * *} \\
(0.042)\end{array}$ & $\begin{array}{c}-2.121^{* * * *} \\
(0.042)\end{array}$ & $\begin{array}{l}-0.034 \\
(0.042)\end{array}$ & $\begin{array}{c}-0.597^{* * *} \\
(0.251)\end{array}$ & $\begin{array}{c}-0.916^{* * *} \\
(0.242)\end{array}$ & $\begin{array}{c}-3.749 * * * * \\
(0.296)\end{array}$ & $\begin{array}{l}-0.124 \\
(0.261)\end{array}$ & $\begin{array}{c}-0.727^{* * *} \\
(0.240)\end{array}$ \\
\hline \multirow[t]{2}{*}{$\begin{array}{l}\sigma^{2} \\
\text { Obs. }\end{array}$} & $\begin{array}{l}0.121 \\
4063\end{array}$ & $\begin{array}{l}0.121 \\
4062\end{array}$ & $\begin{array}{l}0.087 \\
4063\end{array}$ & $\begin{array}{l}0.121 \\
4063\end{array}$ & $\begin{array}{l}0.121 \\
4063\end{array}$ & $\begin{array}{l}0.516 \\
4063\end{array}$ & $\begin{array}{l}0.511 \\
4062\end{array}$ & $\begin{array}{l}0.501 \\
4063\end{array}$ & $\begin{array}{l}0.514 \\
4063\end{array}$ & $\begin{array}{l}0.518 \\
4062\end{array}$ \\
\hline & \multicolumn{10}{|c|}{ Firms with high degree of financial constraint } \\
\hline Size & $\begin{array}{c}0.050^{* * *} \\
(0.015)\end{array}$ & $\begin{array}{l}0.029^{*} \\
(0.015)\end{array}$ & $\begin{array}{c}0.069 * * * \\
(0.015)\end{array}$ & $\begin{array}{c}0.061^{* * *} \\
(0.015)\end{array}$ & $\begin{array}{c}0.055^{* * *} \\
(0.014)\end{array}$ & $\begin{array}{l}-0.001 \\
(0.026)\end{array}$ & $\begin{array}{c}0.004 \\
(0.026)\end{array}$ & $\begin{array}{c}0.008 \\
(0.026)\end{array}$ & $\begin{array}{c}0.008 \\
(0.026)\end{array}$ & $\begin{array}{c}0.008 \\
(0.026)\end{array}$ \\
\hline Lev & $\begin{array}{c}-0.017^{* * *} \\
(0.006)\end{array}$ & $\begin{array}{c}-0.013^{* *} \\
(0.006)\end{array}$ & $\begin{array}{c}-0.017^{* * *} \\
(0.006)\end{array}$ & $\begin{array}{c}-0.018^{* * *} \\
(0.006)\end{array}$ & $\begin{array}{c}-0.015^{* * *} \\
(0.006)\end{array}$ & $\begin{array}{l}-0.0003 \\
(0.001)\end{array}$ & $\begin{array}{c}-0.0004 \\
(0.001)\end{array}$ & $\begin{array}{l}-0.0003 \\
(0.001)\end{array}$ & $\begin{array}{l}-0.0003 \\
(0.001)\end{array}$ & $\begin{array}{l}-0.0002 \\
(0.001)\end{array}$ \\
\hline Growth & $\begin{array}{c}0.135^{* * *} \\
(0.040)\end{array}$ & $\begin{array}{c}0.091^{* * *} \\
(0.038)\end{array}$ & $\begin{array}{c}0.135^{* * *} \\
(0.039)\end{array}$ & $\begin{array}{c}0.138^{* * *} \\
(0.040)\end{array}$ & $\begin{array}{c}0.111 * * * \\
(0.038)\end{array}$ & $\begin{array}{c}0.168^{* * *} \\
(0.049)\end{array}$ & $\begin{array}{c}0.182^{* * *} \\
(0.049)\end{array}$ & $\begin{array}{c}0.164^{* * *} \\
(0.049)\end{array}$ & $\begin{array}{c}0.168^{* * *} \\
(0.049)\end{array}$ & $\begin{array}{c}0.161^{* * *} \\
(0.049)\end{array}$ \\
\hline$A Q$ & $\begin{array}{c}-1.197^{* * *} \\
(0.440)\end{array}$ & & & & & $\begin{array}{l}0.747 \\
(0.905)\end{array}$ & & & & \\
\hline PV & & $\begin{array}{c}-0.019 * * * \\
(0.001)\end{array}$ & & & & & $\begin{array}{c}0.005^{* * *} \\
(0.002)\end{array}$ & & & \\
\hline $\mathrm{FV}$ & & & $\begin{array}{c}0.336^{* * *} \\
(0.054)\end{array}$ & & & & & $\begin{array}{c}0.005^{* * *} \\
(0.002)\end{array}$ & & \\
\hline AAA & & & & $\begin{array}{c}0.005 \\
(0.004)\end{array}$ & & & & & $\begin{array}{l}0.012^{* *} \\
(0.005)\end{array}$ & \\
\hline IQF & & & & & $\begin{array}{c}-0.316^{* * *} \\
(0.030)\end{array}$ & & & & & $\begin{array}{l}-0.064 \\
(0.041)\end{array}$ \\
\hline Cons & $\begin{array}{c}-0.663^{* *} \\
(0.321)\end{array}$ & $\begin{array}{l}-0.033 \\
(0.281)\end{array}$ & $\begin{array}{c}-1.286^{* * *} \\
(0.341)\end{array}$ & $\begin{array}{c}-0.880^{* * *} \\
(0.338)\end{array}$ & $\begin{array}{c}-0.720^{* *} \\
(0.327)\end{array}$ & $\begin{array}{c}0.514 \\
(0.522)\end{array}$ & $\begin{array}{c}0.674 \\
(0.459)\end{array}$ & $\begin{array}{l}-0.153 \\
(0.532)\end{array}$ & $\begin{array}{c}0.104 \\
(0.526)\end{array}$ & $\begin{array}{c}0.240 \\
(0.522)\end{array}$ \\
\hline $\begin{array}{l}\sigma^{2} \\
\text { Obs. }\end{array}$ & $\begin{array}{l}0.740 \\
2014\end{array}$ & $\begin{array}{l}0.720 \\
2040\end{array}$ & $\begin{array}{l}0.734 \\
2040\end{array}$ & $\begin{array}{l}0.740 \\
2040\end{array}$ & $\begin{array}{l}0.722 \\
2040\end{array}$ & $\begin{array}{l}0.845 \\
2040\end{array}$ & $\begin{array}{l}0.844 \\
2040\end{array}$ & $\begin{array}{l}0.843 \\
2040\end{array}$ & $\begin{array}{l}0.844 \\
2040\end{array}$ & $\begin{array}{l}0.844 \\
2040\end{array}$ \\
\hline
\end{tabular}

Size is the size of the firm in thousands of U.S. dollars, Lev is the Leverage, Growth is sales variation, AQ is the Accruals Quality, PV is Predictive Value, FV is the Feedback Value, AAA is Absolute Abnormal Accruals, IQF is Information Quality Factor. In parentheses are reported the standard deviations. The symbols *,*** and ${ }^{* *}$ are $10 \%, 5 \%$ and $1 \%$ significance level, respectively. 
The third variable to represent the quality of accounting is the Feedback Value. The results show that there is a positive and significant relationship between Return on Equity (model II) and Market to book (model VIII). This variable has a positive relationship with the quality of accounting information, i.e., the higher the predictive value, the better the quality of accounting information. The same result was obtained for all the groups of firms. Therefore, it is possible to affirm that the high accounting quality, measured by Feedback Value, improves the investment opportunities and performance of Latin American companies. The findings confirm the idea that there is a positive and significant relationship between accounting information quality and performance of Latin American companies.

The forth proxy of accounting quality is the Absolute Abnormal Accrual that was proposed by Jones (1991). This variable was negative for unconstrained firms in relation to Return on equity (model IV) and positive for all others groups of firms. Although the positive sign is opposite to that expected for Market to book for unconstrained firms, this can be explained by the fact this proxy considers the possibility of discretionary management of accounting numbers. Similar to the Predictive Value, the positive value for Abnormal Accrual can be explained by considering that a firm's market value is more influenced by revenue growth than quality of accounting information. For constrained firms, despite the sales growth, it has an important Market to Book weight.

The last proxy for earnings quality is the grouping of four proxies for earnings quality that were previously presented. The variable Accrual Quality Factor presented a positive and significant relationship with Market to book value for unconstrained firms and for firms in the intermediate situation (model $\mathrm{X}$ ) and negative and significant relationship with Return on Equity for all groups. This variable is not significant to explain the investment opportunities for constrained firms and indicates that an improvement on the quality of accounting information will reduce the operational performance for constrained firms. One possible explanation for this is that constrained firms are in more difficult financial conditions and an improvement on accounting information quality will be reflected in higher borrowing costs.

The second approach explored in this paper analyzes the relationship between quality of accrual and investment opportunities using a modified version of the investment model that was proposed by Jorgenson (1963) and previously presented. The firms were divided according to the level of financial constraint and the constraint was measured by the $\mathrm{KZ}$ index. This measurement was proposed by Lamont, Polk \& Saa-Requejo (2001) and reflects the likelihood that a firm faces financial constraints. We measured the KZ for all companies and divided the initial data base into tree terciles: the first group consists of companies with lower levels of $\mathrm{KZ}$, i.e., unconstrained, the second group includes companies in an intermediate financial situation and, finally, the third group includes financially constrained firms, i.e., firms with a high level in the KZ index. The results are presented in table 4 using the fixed effect model and the mixed model. Each equation, the firm-specific effect and time-effect are fixed, the estimation of mixed model includes random country effect. The random country effect is included to incorporate an extra randomness on the unobserved heterogeneity of the country 4 . To check whether the macroeconomic effects affect differently each country, we consider the country as a second level with time dummies as random variable varying by country in the mixed model. The results show that the macroeconomic policies (time dummies) effects vary by country and are significant for most of the period. In addition, the intraclass correlation shows significant between and within effects of firms' and countries' covariates. 
Table 4: Investment Model using Fixed and Mixed Model

\begin{tabular}{|c|c|c|c|c|c|c|}
\hline \multirow{2}{*}{ Variables } & \multicolumn{2}{|c|}{ Unconstraint } & \multicolumn{2}{|c|}{ IFS } & \multicolumn{2}{|c|}{ Constraint } \\
\hline & $\mathrm{FE}$ & MM & $\mathrm{FE}$ & MM & $\mathrm{FE}$ & MM \\
\hline$\left(1 / K_{j t-1}\right)_{j t-1}$ & $\begin{array}{c}-0.436^{* * *} \\
(0.065)\end{array}$ & $\begin{array}{c}-0.353^{* * *} \\
(0.059)\end{array}$ & $\begin{array}{c}-0.129^{* * *} \\
(0.016)\end{array}$ & $\begin{array}{c}0.009^{* * *} \\
(0.001)\end{array}$ & $\begin{array}{c}-0.084^{* * *} \\
(0.020)\end{array}$ & $\begin{array}{c}-0.087^{* * *} \\
(0.019)\end{array}$ \\
\hline$\left(I / K_{j t-1}\right) 2_{j t-1}$ & $\begin{array}{c}0.055^{* * *} \\
(0.055)\end{array}$ & $\begin{array}{c}0.004 \\
(0.003)\end{array}$ & $\begin{array}{c}-0.129 * * * \\
(0.016)\end{array}$ & $\begin{array}{c}0.009^{* * *} \\
(0.001)\end{array}$ & $\begin{array}{c}0.013^{* * *} \\
(0.002)\end{array}$ & $\begin{array}{c}0.013^{* * *} \\
(0.001)\end{array}$ \\
\hline$\left(\mathrm{S} / \mathrm{K}_{\mathrm{jt}-1}\right)_{\mathrm{jt}}$ & $\begin{array}{c}0.004 \\
(0.003)\end{array}$ & $\begin{array}{c}0.004 \\
(0.003)\end{array}$ & $\begin{array}{c}-0.021^{* * *} \\
(0.005)\end{array}$ & $\begin{array}{c}-0.023^{* * *} \\
(0.005)\end{array}$ & $\begin{array}{c}0.124^{* * *} \\
(0.008)\end{array}$ & $\begin{array}{c}0.132^{* * *} \\
(0.008)\end{array}$ \\
\hline$\left(C F / K_{j t-1}\right)_{j t}$ & $\begin{array}{c}0.122^{* * *} \\
(0.021)\end{array}$ & $\begin{array}{c}0.121 * * * \\
(0.021)\end{array}$ & $\begin{array}{c}0.327^{* * *} \\
(0.032)\end{array}$ & $\begin{array}{c}0.335^{* * * *} \\
(0.031)\end{array}$ & $\begin{array}{c}0.115^{* * *} \\
(0.033)\end{array}$ & $\begin{array}{c}0.108^{* * *} \\
(0.031)\end{array}$ \\
\hline$\left(D / K_{j t-1}\right)_{j t}$ & $\begin{array}{c}0.005 \\
(0.004)\end{array}$ & $\begin{array}{c}0.005 \\
(0.004)\end{array}$ & $\begin{array}{c}0.259^{* * * *} \\
(0.008)\end{array}$ & $\begin{array}{c}0.275^{* * *} \\
(0.008)\end{array}$ & $\begin{array}{c}0.025^{* * *} \\
(0.004)\end{array}$ & $\begin{array}{c}0.027^{* * *} \\
(0.004)\end{array}$ \\
\hline IQF & $\begin{array}{c}-0.147^{* *} \\
(0.062)\end{array}$ & $\begin{array}{c}-0.120^{* *} \\
(0.057)\end{array}$ & $\begin{array}{c}-0.073^{* * *} \\
(0.019)\end{array}$ & $\begin{array}{c}-0.061^{* * *} \\
(0.019)\end{array}$ & $\begin{array}{l}-0.019 \\
(0.012)\end{array}$ & $\begin{array}{l}-0.027^{* *} \\
(0.012)\end{array}$ \\
\hline $\begin{array}{l}R^{2} \\
\sigma^{2}\end{array}$ & $\begin{array}{l}0.094 \\
1.378\end{array}$ & $\begin{array}{c}0.125 \\
1.38\end{array}$ & $\begin{array}{l}0.285 \\
0.183\end{array}$ & $\begin{array}{l}0.121 \\
0.183\end{array}$ & $\begin{array}{l}0.226 \\
0.169\end{array}$ & $\begin{array}{c}0.247 \\
0.17\end{array}$ \\
\hline IC Firms & & $\begin{array}{c}0.153 \\
(0.107)\end{array}$ & & $\begin{array}{c}0.343 \\
(0.079)\end{array}$ & & $\begin{array}{c}0.387 \\
(0.099)\end{array}$ \\
\hline $\begin{array}{l}\text { IC Countries / } \\
\text { Firms }\end{array}$ & & $\begin{array}{c}0.960 \\
(0.050)\end{array}$ & & $\begin{array}{c}0.881 \\
(0.034)\end{array}$ & & $\begin{array}{c}0.899) \\
(0.034)\end{array}$ \\
\hline Obs. & \multicolumn{2}{|c|}{1689} & \multicolumn{2}{|c|}{3767} & \multicolumn{2}{|c|}{1900} \\
\hline
\end{tabular}

IFS is firms with intermediate financial situation, I is investments, $K$ is capital stock, $S$ is sales, CF is cash flow, D is debt, IQF is Information Quality Factor.In parentheses are reported the standard deviations. The symbols **** and ${ }^{* * *}$ are $10 \%, 5 \%$ and $1 \%$ significance level, respectively, IC is interclass correlation.

The sales variable presented a positive relationship with the investment, but for unconstrained firms this variable was not significant. For constrained firms this variable is significant, with a higher coefficient. The possible explanation of this result is that constrained firms have more dependency of sales in order to make cash holdings and therefore conduct more investments.

The Cash Flow variable indicates a proxy for liquidity, although it provides information about future investment opportunities. Our results show that the cash flow is positive and significantly related with investment for all groups. Unconstrained firms presented higher investment-cash flow sensitivity than constrained firms. This indicates that the investment cash flow sensitivity does not signal financial constraints.

The financing variable measures the impact of debt on the investment decisions, the results presented below showed that for unconstrained and constrained firms the debt has a positive impact on investment. This occurs because our sample contains data of developing countries. The most developed capital markets have facilities to access indebtedness and least developed capital markets of developing countries may create difficulties to obtain new loans. Because of this, it was expected that the relationship between financing and investment would be positive. Our result corroborates with the studies of Arbelaéz \& Echavarrria (2002) for Colombia, Fanelli, Bebczuk \& Pradelli (2002) for Argentina and Kalatzis, Azzoni \& Achcar (2008) for Brazil, which found a positive relationship between leverage and capital investment.

The Accrual Quality Factor variable resumes our four proxies for quality of accounting information. This variable is composed of Feedback Value, Predictive Value, Absolute Abnornal Accrual and Accrual Quality. The weight of Predictive Value and Accrual quality, variables that have a negative relationship with earnings quality, is higher. Therefore, the higher the factor accruals quality, the lower the earnings quality. The results presented in the Table 4 showed that for unconstrained and constrained firms the factors have a negative impact on the investment, i.e., one variation on quality of accrual will be positively impact the level of investment. However, the improvement in the quality of financial information is more strongly positive among unconstrained firms. 
This paper makes an important contribution to the literature. First, the major contribution of this paper is to discuss the role of the quality of accounting information on the performance and investment of Latin American firms, especially when considering the scarcity of research in this area for these countries. We used two firm performance variables to investigate the role of accounting information quality on the performance of both accounting and market. Although the quality of accounting information involves different aspects, it can be understood as useful decision-making information, which is related with the relevance and reliability of accounting information. Therefore, it is expected that firms with a better quality level in their accounting information can present better operational performance. Another important contribution is that our measure of account quality plays a significant role on firms' investment, as well as being a useful proxy for the financial constraints. Secondly, this study is based on a cross-country data, from 1989 to 2009, of the seven largest economies in Latin American. While most works use data covering a short period of time, our database includes long-span periods, which can capture the changes in economic policy and periods of economic turbulence. Thirdly, our work to predict investment models uses mixed models, which enable capturing the unobserved heterogeneity of the cross section units by incorporating an additional randomness on the explanatory variables, we also used a country-specific effect aiming at controlling the unobserved characteristics. As pointed out by Weinhold (1999), a model that allows considering the heterogeneity in the coefficient of the explanatory variables avoids the bias introduced by heterogeneity, mainly on the lagged dependent variable.

\section{CONCLUSIONS}

This paper has analyzed the impact of earnings quality on investment decisions and on firm's operational performance. The firms were grouped according to the financial conduction in three groups, the financial constraints, unconstraint and others. The groups were defined through the KZ index level and this group was used to analyze the differences between constrained and unconstrained firms in the analysis. Using a mixed model set consisting of 596 Latin American firms for the period of 1989 to 2009, this paper finds two main contributions.

First, our results corroborate with the theory that the quality of accounting information has a positive and significant impact on the operational performance of firms. In addition, our results shown that firms with better accounting information have the best investments opportunities. When the investment opportunities are measured by the Market to book, the higher financial information quality has a positive impact on the investment opportunities. The same result was obtained by using the modified investment model, which indicates that the quality of accounting information is significant to explain the investment decisions. Thus, a firm's performance may be influenced by factors related to a firm's prospects of growth, size, operational efficiency and leverage. This finding shows to be consistent when we consider that the leverage coefficient is not significant for a firm's investment opportunities, signalizing that the market does not assign high importance to a firm's leverage, despite the fact that it is significant for the Return on Equity.

Secondly, we investigate the presence of financial constraint on investment decisions by comparing the estimates of accounting quality across groups of firms classified according to the KZ index. Herein, the model of investment was estimated considering a mix of effects, i.e., we use the mixed-effect model that considers covariates involving both random and fixed effects. The mixed-effect model allows incorporating an extra randomness on the explanatory variables and capturing the unobserved 
heterogeneity of the cross-section units. This approach is more plausible in this study, as it can provide better estimates by reducing the homogeneity assumptions that are often imposed on the coefficients of the lagged dependent variable. Assuming that the coefficients of the lagged dependent variable are constant can lead to serious biases when they are heterogeneous across the cross-section units (Weinhold, 1999). Our results further showed that the accounting quality appears to be a useful proxy for financial constraint. The coefficient of accounting quality is negative and significant to explain investment for all the groups of firms. In addition to the negative relationship between investment and accounting quality, we also observed that this relationship is more powerful for unconstrained firms.

The results of this study suggest that the quality of accounting information has a positive and significant impact on the operational performance and a positive impact on the investment opportunities. The managerial consequence of this study is that the adoption of mechanisms to improve the quality of accounting information is important to be able board monitoring more effective. Future research should focus on estimating of model controlling the factors that could change the results and analysis, like the grouping firms by size, economic sector, capital intensity or different proxies for constraints. We also recommend to future studies the investigation of simultaneity between accounting information quality and performance.

\section{REFERENCES}

Aboody, D., Hughes, J. \& Liu, J. (2005). Earnings quality, insider trading, and cost of capital. Journal of Accounting Research, Vol.43, p.651-673.

Allayannis, G., \& Mozumdar, A. (2004). The impact of negative cash flow and influential observations on investment-cash flow sensitivity estimates. Journal of Banking and Finance, 28, 901-930.

Almeida, H., Campello, M., \& Weisbach, M. S. (2004). The cash flow sensitivity of cash. The Journal of Finance, 59(4), 1777-1804.

Antunes, G. A \& Costa, F. M. S. S. (2007). Governança e qualidade da informação contábil: uma investigação utilizando empresas brasileiras que aderiram ou não aos níveis diferenciados de Governança da Bovespa. Anais do 31 Encontro da Associação Nacional de Pós-graduação e Pesquisa em Administração. Rio de Janeiro.

Antunes, G. A, Mendonça, M. M. D., Azevedo, F. B. \& Alencar, R. C. (2008). Empresas estatais federais e empresas do novo mercado da Bovespa: um estudo comparativo acerca da qualidade da informação contábil utilizando dados em painel. Anais do $8^{\circ}$. Congresso USP de Controladoria e Contabilidade, São Paulo.

Arbeláez, M. A. \& Echavarria, J. J. (2002). Credit, Financial Liberalization and Manufacturing Investment in Colombia. IDB Working Paper No. 160. Available at SSRN: http://ssrn.com/abstract=1814709 or http:// dx.doi.org/10.2139/ssrn.1814709

Ball, R \& Shivakumar, L. (2006). The role of accruals in asymmetrically timely gain and loss recognition. Journal of Accounting Research, Vol.44, p.207-242.

Barbosa, J., Scherer, L., Scarpin, J., \& Murcia, F. (2015). Construção de métrica para avaliação da qualidade da informação contábil sob a ótica de analistas fundamentalistas. Revista de Contabilidade e Organizações, 9 (24), 42-55. doi: http://dx.doi.org/10.11606/rco.v9i24.79534 
Barth, M. E., Beaver, W. H. \& Landsman, W. R (2001) The relevance of the value relevance literature for financial accounting standard setting: Another view. Journal of Accounting and Economics, Vol.31, p.77-104.

Barua, A. (2005). Using the FASB's qualitative characteristics in earnings quality measures. Available at SSRN 815784, viewed 28 July 2010.

Bédard, J, Chtourou, S. M. \& Courteau, L. (2004). The effect of audit committee expertise, independence, and activity on aggressive earnings management. Auditing, Vol.23, p.13-35.

Bhagat, S., Moyen, N., \& Suh, I. (2005). Investment and internal funds of distressed firms. Journal of Corporate Finance, 11, 449-472.

Biddle, G. C., Hilary, G. \& Verdi, R. S. (2009). How does financial reporting quality relate to investment efficiency?. Journal of Accounting and Economics, Vol.48, p.112-131.

Bushman, R. M. \& Smith, A.J. (2001). Financial accounting information and corporate governance. Journal of Accounting and Economics, Vol.32, p.237-333.

Carvalho, F. L., Kalatzis, A. E. G., \& de Albuquerque, A. A. (2014). The relationship between earnings quality and the probability of efficient investment decisions in Latin America. Latin American Journal of Management for Sustainable Development, 1(2-3), 229-250.

Cleary, S., Povel, P., \& Raith, M. (2007). The U-shaped investment curve: Theory and evidence. Journal of Financial and Quantitative Analysis, 42, 1-40.

Coelho, A. C. D., \& Lopes, A. B. (2007). Avaliação da prática de gerenciamento de resultados na apuração de lucro por companhias abertas brasileiras conforme seu grau de alavancagem financeira. Revista de Administração Contemporânea, 11 (spe2), 121-144. https://dx.doi.org/10.1590/S141565552007000600007

Colauto, R. D., \& Beuren, I. M. (2006). Um estudo sobre a influência de accruals na correlação entre o lucro contábil e a variação do capital circulante líquido de empresas. Revista de Administração Contemporânea, 10(2), 95-116.

Corea, J. E., Guay, W. R. \& Verdi, R. (2008). Is accruals quality a priced risk factor?. Journal of Accounting and Economics, Vol.46, p.2-22.

Costa, D. F., \& Carvalho, F. M. (2016). Relação entre gerenciamento de resultado e governança corporativa: construindo um referencial teórico a partir de uma revisão sistemática da literatura. ForScience, $4(1), 20-41$.

Costa, F. M., Lopes, A. B., \& Costa, A. C. O. (2006). Conservadorismo em cinco países da América do Sul. Revista Contabilidade \& Finanças - USP, 17(41), 7-20.

Dechow, P., Ge, W., \& Schrand, C. (2010). Understanding earnings quality: a review of the proxies, their determinants and their consequences. Journal of Accounting and Economics, v.50, n.2/3, p.344-401.

Dechow, P. M. \& Dichev, I. D. (2002). The quality of accruals and earnings: The role of accrual estimation errors. Accounting Review, Vol.77, p.35-59.

Dechow, P. M. \& Sloan, R. G. (1991). Executive incentives and the horizon problem. An empirical investigation. Journal of Accounting and Economics, Vol.14, p.51-89. 
Defond, M. L., \& Jiambalvo, J. (1994). Debt covenant violation and manipulation of accruals. Journal of Accounting \& Economics, 17(1-2), 145-176.

Devereux, M., \& Schiantarelli, F. (1989). Investment, Financial Factor, and Cash Flow: Evidence from U.K Panel Data. In hubbard, R.G. Asymmetric Information, Corporate Finance, and Investment. Chicago: Chicago University Press.

Fanelli, J. M., Bebczuk, R. \& Pradelli, J. (2002). Determinants and Consequences of Financial Constraints Facing Firms in Argentina. IDB Working Paper No. 162.

Fazzari, S. M., Hubbard, G., \& Peters E. N. B. (1988). Financing constraints and corporate investment. Brookings Papers on Economic Activity, 1, 1988, 141-95.

Fazzari, S. M. \& Petersen, B. C. (1993). Working capital and fixed investment - new evidence on financing constraints, Rand Journal of Economics, Vol.24, p.328-342.

Financial Accounting Standards Board [Fasb]. (1978). Objectives of financial reporting by business enterprises. Novembro.

Francis, J, Lafond, R, Olsson, P \& Schipper, K. (2005). The market pricing of accruals quality. Journal of Accounting and Economics, Vol.39, p.295-327.

Francis, J, Lafond, R, Olsson, P. M \& Schipper, K. (2004) Costs of equity and earnings attributes, Accounting Review, Vol.79, p.967-1010.

Francis, J, Nanda, D. \& Olsson, P. (2008). Voluntary Disclosure, Earnings Quality, and Cost of Capital. Journal of Accounting Research, Vol.46, p.53-99.

Francis, J, Schipper, K. \& Vincent, L. (2003). The relative and incremental explanatory power of earnings and alternative (to earnings) performance measures for returns. Contemporary Accounting Research, Vol.20, p.121-164.

Ghosh, A., \& Moon, D. (2010). Corporate debt financing and earnings quality. Journal of Business Finance \& Accounting, v.37, n.5/6, p.538-559.

Gu, Z., Lee, C. W. J., \& Rosett, J. G. (2005). What determines the variability of accounting accruals?. Review of Quantitative Finance and Accounting, 24(3), p. 313-334.

Healy, P. M. \& Wahlen, J. M. (1999). A review of the earnings management literature and its implications for standard setting. Accounting Horizons, Vol.13, p.365-383.

Hendriksen, E. S. \& Van Breda, M. F. (1999). Teoria da contabilidade, Atlas, São Paulo.

Himmelberg, C. P., Hubbard, R. G., \& Palia, D. (1999). Understanding the determinants of managerial ownership and the link between ownership and performance. Journal of Financial Economics, 53(3), 353-384.

Hsiao, C., \& Tahmiscioglu, K., (1997). A panel analysis is of liquidity constraint and firm investment. Journal American Statistical Association 92, 455-465.

Inci, A. C., Lee, B. S. \& Suh, J. (2009). Capital investment and earnings: International evidence. Corporate Governance, Vol.17, p. 526-545.

Jones, J. J. (1991). Earnings Management During Import Relief Investigations. Journal of Accounting Research, Vol.29, p.193-228. 
Jorgenson, W. D. (1963). Capital theory and investment behavior. The American Economic Review, 53, 247-59.

Kalatzis, A. E. G., Azzoni, C. R., \& Achcar, J. A. (2008). Financial constraints and investment decisions: evidence from a highly unstable emerging economy. Applied Economics, 40(11), 1425-1434.

Kaplan, S., \& Zingales, L. Do investment-cash flow sensitivities provide useful measures of financing constraints? Quarterly Journal of Economics, 122(1), 1997, 169-215.

Kim, D \& Qi, Y. X. (2010). Accruals Quality, Stock Returns, and Macroeconomic Conditions. Accounting Review, Vol.85, p.937-978.

Kormendi, R \& Lipe, R. (1987). Earnings innovations, earnings persistence, and stock returns. Journal of Business, Vol.60, p.323-345.

Lambert, R, Leuz, C \& Verrecchia, R. E. (2007). Accounting information, disclosure, and the cost of capital. Journal of Accounting Research, Vol.45, p.385-420.

Lamont, O., Polk, C., \& Saá-Requejo, J. (2001). Financial constraints and stock returns. Review of Financial Studies, v.14, n.2, p.529-554.

Larcker, D. F, Richardson, S. A. \& Tuna, I. (2007). Corporate governance, accounting outcomes, and organizational performance. Accounting Review, Vol.82, p.963-1008.

Lima, A. S., Carvalho, E. V. A., Paulo, E., \& Girão, L. F. A. P. (2015). Life Cycle Stages and Earnings Quality in Brazil. Revista de Administração Contemporânea, 19(3), 398-418. https://dx.doi.org/10.1590/ 1982-7849rac20151711

Lindstrom, M. J., \& Bates, D. M. (1988). Newton-Raphson and EM Algorithms for Linear Mixed-Effects Models for Repeated-Measures Data. Journal of the American Statistical Association, 83, 1014-22.

Loss, L., \& Sarlo Neto, A. (2006). O inter-relacionamento entre políticas de dividendos e de investimentos: estudo aplicado às companhias brasileiras negociadas na Bovespa. Revista Contabilidade \& Finanças, 17(40), 52-66.

Mazzioni, S., Prigol, V., Moura, G., \& Klann, R. (2016). Influência da governança corporativa e da estrutura de capital no gerenciamento de resultados. Revista Contemporânea de Contabilidade, 12(27), 61-86. doi:http://dx.doi.org/10.5007/\%x

Mahmud, R., Ibrahim, M. K., \& Pok, W. C. (2009). Earnings Quality Attributes and Performance of Malaysian Public Listed Firms. Available at SSRN 1460309.

McNichols, M. F. (2002). Discussion of the quality of accruals and earnings: The role of accrual estimation errors. Accounting Review, Vol.77, p.61-69.

Myers, J. N., Myers, L. A. \& Omer, T. C. (2003). Exploring the term of the auditor-client relationship and the quality of earnings: A case for mandatory auditor rotation?. Accounting Review, Vol.78, p.779-799.

Ozkan, A. \& Ozkan, N. (2004). Corporate cash holdings: An empirical investigation of UK companies. Journal of Banking \& Finance, Vol.28, p.2103-2134.

Penman, S. H., \& Zhang, X. J. (2002). Accounting conservatism, the quality of earnings, and stock returns. The accounting review, 77(2), p. 237-264. 
Portal, M. T., Zani, J. \& Silva, C. E. S. (2012). Fricções financeiras e a substituição entre fundos internos e externos em companhias brasileiras de capital aberto. Revista Contabilidade \& Finanças, 23(58), $19-32$. https://dx.doi.org/10.1590/S1519-70772012000100002

Potin, S. A., Bortolon, P. M., \& Sarlo Neto, A. S. (2016). Hedge Accounting no Mercado Acionário Brasileiro: Efeitos na Qualidade da Informação Contábil, Disclosure e Assimetria de Informação. Revista Contabilidade \& Finanças, 27(71), 202-216.

Santos, L. S. R., \& da Costa, F. M. (2008). Conservadorismo contábil e timeliness: evidências empíricas nas demonstrações contábeis de empresas brasileiras com ADRs negociados na Bolsa de Nova lorque. Revista Contabilidade \& Finanças, 19(48), 27-36.

Titman, S. \&Wessels, R. (1988). The Determinants Of Capital Structure Choice. Journal of Finance, Vol.43, p.1-19.

Watts, R. L., \& Zimmerman, J. L. (1986). Positive accounting theory. Prentice Hall, Englewood Cliffs, NJ.

Weinhold, D. (1999). A dynamic fixed effects model for heterogeneous panel data, unpublished manuscript, London School of Economics. Mimeo.

Whited, T. M. (1992). Debt, Liquidity Constraints, and Corporate-Investment - Evidence From Panel Data. Journal of Finance, Vol.47, p.1425-1460. 